\title{
Ocean and Coastal Research \\ Ocean Literacy, formal education, and governance: A diagnosis of Brazilian school curricula as a strategy to guide actions during the Ocean Decade and beyond
}

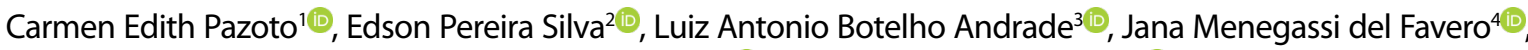 \\ Camilla Ferreira Souza Alô ${ }^{5 \oplus}$, Michelle Rezende Duarte ${ }^{6, *}(0)$ \\ ${ }^{1}$ Fundação Municipal de Educação de Niterói (Rua São Pedro, 108 - Centro, Niterói - 24020-055 - RJ - Brazil) \\ ${ }^{2}$ Universidade Federal Fluminense (Rua Alexandre Moura, 8 - São Domingos - Niterói - 24210-200 - RJ - Brazil) \\ ${ }^{3}$ Prefeitura Municipal de Niterói - Secretaria Municipal de Ciência, Tecnologia e Inovação (Rua Visconde de Sepetiba, 987, $5^{\circ}$ andar - \\ Niterói - 24020-206 - RJ -Brazil) \\ ${ }^{4}$ Universidade Federal do Rio de Janeiro - "Chat with Neptune" (Av. Carlos Chagas Filho, 373- Cidade Universitária - 21941-971 - RJ - Brazil) \\ ${ }^{5}$ Fundacão Municipal de Educacão de Niterói (Rua São Pedro, 108 - Centro - Niterói - 24020-055 - RJ - Brazil)) \\ ${ }^{6}$ Universidade Federal Fluminense (Rua Alexandre Moura, 8 - São Domingos - Niterói - 24210-200 - RJ - Brazil) \\ *Corresponding author: michellerezendeduarte@yahoo.com.br
}

\section{AbSTRACT}

Ocean Literacy (OL) was proposed by UNESCO as a goal for the Decade of Ocean Science for Sustainable Development (Ocean Decade) aiming to (1) increase understanding of the importance of the ocean, (2) significantly influence communication on related subjects, and (3) facilitate informed and responsible decision-making about the ocean and its resources. Formal education is essential to expand the reach of $\mathrm{OL}$, providing people with tools to engage in coastal and marine issues consciously and knowingly. To this end, content analysis of school curricula can help planning strategies, especially to empower citizens to implement public policies. This study assessed the extent to which OL-related terms and words are present in Brazilian curricular documents at federal (National Curriculum Parameters-PCNs and Common National Curriculum Base-BNCC) and regional (Federative Units curricular guidelinesRCs) levels. Qualitative (content analysis) and quantitative analyses (descriptive and non-parametric statistics, and multivariate analysis) were performed. The number of occurrences of OL-related words and terms were registered and counted. Nineteen words were found, totaling 797 citations (a frequency of 0.0001 in the total number of words referring to content). The number of citations were higher in BNCC-based RCs than in PCN-based RCs (Kruskal-Wallis test, $p=0.0009$ ). Principal component analysis separated the documents into two groups, one related to BNCC-based RCs of Northeast, North and Midwest regions, with a higher number of OL related terms, and the other group with the PCN based RCs of these same regions plus those documents of Southeast and South regions (principal component 1 explaining $97.90 \%$ of the total variation and having 0.93 correlation with the total frequency of citations). General results indicated that Brazilian production on fields and themes related to $\mathrm{OL}$ is still concentrated in national journals, books, and booklets, thus with a limited impact. In same way although school curricula in Brazil have a larger number of topics on marine environments than do other countries, they showed heterogeneity among Federative Units, but generally with the topics still representing a very small fraction of Brazilian curricula. Thus, it is necessary to expand the contents related to the ocean and marine environments in curricula to provide students with basic knowledge about the importance and functions of these environments, as well as their conservation. Therefore, results here emphasize the need to implement OL to highlight the importance of knowledge of the oceans and enable citizens to discuss marine conservation policies and promote ocean sustainability. This study provided some strategies to increase $\mathrm{OL}$ in formal education and, hence, reach various stakeholders, which is fundamental to implement the United Nations Ocean Decade in Brazil and the Global South.

Descriptors: Marine science, Public policies, Stakeholders, Citizenship, Quantitative analysis.

Submitted: 16-February-2021

Approved: 31-December-2021

Associate Editor: Alexander Turra

(c) 2021 The authors. This is an open access article distributed under

the terms of the Creative Commons license. 


\section{OCEAN LITERACY}

\section{A WORLD VIEW OF THE SCIENTIFIC PRODUCTION}

The Ocean Literacy (OL) movement started in the United States in the early 2000s from discussion between scientists and educators to raise public awareness of marine conservation (Schoedinger et al., 2010). It was encouraged by the North American commission reports on Marine Ecology, America's Living Oceans by the Pew Oceans Commission in 2003 (Pew Oceans Commission, 2003) and An Ocean Blueprint for the 21st Century by the US Commission on Ocean Policy in 2004 (US Commission on Ocean Policy, 2004). Both reports recognize that ocean themes should be incorporated into formal curriculum for marine conservation and sustainability purposes.

Incorporation of Ocean Sciences-related topics into formal education was first discussed in 2002, in an online conference themed "Oceans for Life", which was promoted by the College of Exploration and the National Geographic Society (Ocean Literacy Network, 2013). In 2004, in an online workshop with about 100 attendees engaged in ocean education, OL was defined as "understanding the human influence on the ocean and the ocean influence on humans". It is a broad, collaborative, and decentralized effort by scientists and educators to form a community with broader knowledge about the functions and importance of the ocean, increasing public awareness about this environment for conservation purposes (Santoro et al., 2017). Yet, in 2004 it was established what is expected from an ocean literate person: (1) understand fundamental concepts about ocean functioning, (2) communicate meaningfully about the ocean, and (3) make informed and responsible decisions about the ocean and its resources (Ocean Literacy Network, 2013). A consensus was raised at this event on ocean-related contents to be understood by students at the end of formal education. This agreement was published in a document called "Ocean Literacy - The Essential Principles of Ocean Science K-12". This document contained seven essential principles and 44 fundamental concepts in $\mathrm{OL}$, which were extended to 45 in the last update of the document (Ocean Literacy Network, 2020).
Other countries have identified gaps in OL teaching and used US documents as a reference to implement local changes. For instance, Portugal was one of the first countries to adopt the US OL documents through the initiative "Conhecer o Oceano" (Costa and Caldeira, 2018), and recently, European countries released the document "Mediterranean Sea Literacy" (Mokos et al., 2020). OL has been encouraged by associations of educators, including the European Marine Science Educators Association (EMSEA) and Asia Marine Educators Association (AMEA). Furthermore, collaborative ocean research groups were formed, including the Transatlantic Ocean Research Alliance signed by the European Union, the United States, and Canada (Tuddenham et al., 2013).

Since its inception, OL has served as a tool to provide citizens with basic knowledge on the functions and importance of the ocean, improving discussion on marine conservation and decision-making on the use of marine resources (Ocean Literacy Network, 2013). OL has gained international visibility since UNESCO joined it by releasing the digital platform Ocean Literacy for All and book Ocean Literacy for All: A toolkit (Santoro et al., 2017). The book was translated into five languages, including Portuguese. OL came into the spotlight after United Nations recognition as a strategy for the sustainable use of the ocean and its resources and to achieve the goals of the Decade of Ocean Science for Sustainable Development (referenced hereafter as Ocean Decade; United Nations, 2018).

Bibliometric analysis has shown that $\mathrm{OL}$ research is small, with 32 articles published between 2005 and 2016 (Costa and Caldeira, 2018). An update of this data from 2016 to 2020, using the same methodological parameters, identified 58 articles addressing $\mathrm{OL}$, thus totaling 90 articles over 16 years (Figure 1). Therefore, although small and irregular in the first decade, scientific production in OL has increased since 2013. This pattern can be explained by the larger visibility of OL due to international bodies, including UNESCO.

Content analysis (Bardin, 2011) of publications showed six recurrent themes, with greater representation related to education (teaching materials, games, pedagogical activities, and curriculum) (Table 1). Topics recently added to the database include citizen science and $\mathrm{OL}$ discussion through art 


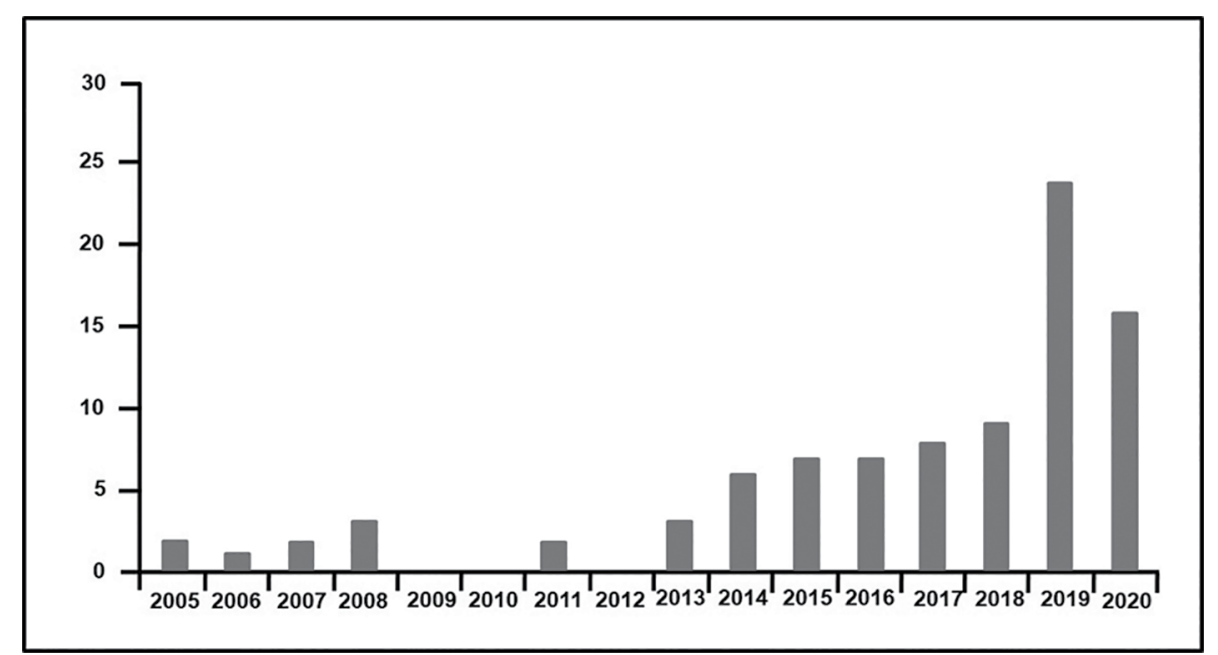

Figure 1. Number of articles on ocean literacy published between 2005 and 2020.

Table 1. Number and percentage of themes in the scientific literature on Ocean Literacy. Legend: $N=$ total number of articles dealing with each of the defined themes.

\begin{tabular}{|c|c|c|c|}
\hline THEME & $\mathbf{N}$ & $\%$ & \\
\hline 1. Knowledge/Perception & 25 & 27.80 & \\
\hline 1.1. General Public & 12 & & 13.30 \\
\hline 1.2. Students & 10 & & 11.10 \\
\hline 1.3. Teachers & 3 & & 3.30 \\
\hline 2. Ocean Literacy Challenges, Opportunities, Recommendations & 8 & 8.90 & \\
\hline 3. Teaching & 40 & 44.40 & \\
\hline 3.1. Formal & 26 & & 28.90 \\
\hline 3.2. Informal & 11 & & 12.20 \\
\hline 3.3. Both formal and informal & 3 & & 3.30 \\
\hline 4. Communication & 6 & 6.70 & \\
\hline 5. Citizen science & 2 & 2.20 & \\
\hline 6. Others* & 9 & 10.00 & \\
\hline TOTAL & 90 & 100 & \\
\hline
\end{tabular}

*This category stands for publications which show a variegated sample of themes such as tourist scuba diving, sustainable consumption of seafood, habitat conservation, motivations for a marine biologist career, coastal populations and economic exploration of the ocean, among others. Although they fit well under OL studies, they are not numerically expressive or theoretically unified.

movements, social media, and other media outlets. Most studies have been carried out in the United States and Europe. In Australia, Canada, China, Korea, and Taiwan, studies on OL strategies have been published since 2014, whereas South America has only one publication from Brazil (Stefanelli-Silva et al., 2019).

Based on the content analysis, OL has gained prominence as a research field. Also, academic studies on the topic have diversified, especially in North America and Europe. Moreover, efforts have been made to integrate it into school curriculum (Schoedinger et al., 2010) and marine conservation public policies (French et al., 2015). However, OL is still underrated in other parts of the planet, such as the Global South.

Since the ocean is globally interconnected, marine ecosystem benefits and issues have crossed geographical and/or political borders. Thus, efforts to promote $\mathrm{OL}$ are urgent and require strategies on a global scale, but especially in developing countries of the Global South with extensive areas. To achieve the 
Ocean Decade goals and maintain them in the future, public engagement in environmentally friendly behaviors and empowerment to discuss and promote marine management are essential.

\section{Brazilian Perspective}

There is a clear lack of OL-related studies in Latin American countries (Ghilardi-Lopes et al., 2019) as this concept was only adopted later therein. In 2020, the Latin American Education Network for the Ocean (Rede de Educação Latino-Americana para o OceanoRELATO), which comprised a group of educators, scientists, and other stakeholders, was formed to promote international cooperation in OL. In Brazil, OL was adopted in 2019, with the release of the Portuguese version of the book Ocean Literacy for All: A toolkit and official translation of the term "ocean literacy" to "cultura oceânica".

Despite the late arrival of $\mathrm{OL}$, a program with similar objectives had already been developed in Brazil, The Maritime Mentality Program (Programa de Mentalidade Marítima-PROMAR). PROMAR was established in 1997 by the Inter-ministerial Commission for Ocean Resources (Comissão Interministerial para os Recursos do Mar [CIRM]) to enhance Brazilian "maritime mentality" (an awareness of the importance of marine ecosystems, which can be translated as "ocean awareness") and incorporate topics related to the functions and importance of the seas into basic schooling. "Maritime mentality" (or "Ocean awareness") is defined as "individual or collective awareness of the importance of the ocean for the Brazilian nation and development of habits, attitudes, behaviors, or willingness to use ocean resource sustainably" (CEMBRA, 2012). The term has been used in projects to increase knowledge on ocean ecosystems, such as Projeto Grael (Niterói, Rio de Janeiro) and Projeto Aprendendo com o Mar (Learning with the Sea Project of the Federal Institute of Santa Catarina), and in the work of non-governmental organizations (NGOs), such as Núcleo de Educação e Monitoramento Ambiental (Environmental Education and Monitoring Center).

To investigate the scientific production of Brazilian "maritime mentality" programs, bibliographic research was conducted using the Scientific Electronic Library Online database (SciELO), which is a open-access digital library and publication system for Brazilian journals. This search considered publications from 1921 to 2020 and used the terms "Ocean Literacy" (and its Portuguese translations "Alfabetização Oceânica" and "Cultura Oceânica") and "Maritime Mentality". However, no article was retrieved from this search, indicating that there are no Brazilian scientific publications in OL.

Although OL is recent in Brazil, and "maritime mentality" programs have not impacted marine environmental debates and academic production, such issues have been addressed by Environmental Education (EE). This is an educational tool focused on increasing the awareness of communities about their relationship with ecosystems and consequences. $\mathrm{EE}$ aims to change human attitudes and values to improve local conditions. Within the scope of $\mathrm{EE}$, there is a specific area dedicated to coastal environments, the so-called Coastal and Marine Environment Education (Educação Ambiental Costeira Marinha [EACM]). In this area, marine conservation activities have been developed to understand human action effects on marine ecosystems, as well as mitigation of those actions (Berchez et al., 2007; Pedrini et al., 2013).

The first EACM activities in Brazil date from the end of the 1990s. Problems addressed included use of attractive species (sea turtles and spinner dolphins) and coastal marine environments (mangroves and dunes) to promote environmental protection; understanding socioeconomic factors and interactions between stakeholders and the environment, including traditional communities and tourists; use of aquariums to increase environmental awareness; and environmental education through science and biology classes or free courses (Pedrini, 2010b).

In Brazil, EACM activities are still few and have a limited reach when compared to inland EE activities (Berchez et al., 2016). The few articles published on the subject in national and international journals mainly include abstracts presented at meetings, symposia, and other academic events, as well as term papers, dissertations, and theses (Berchez et al., 2016). Pedrini (2010b) found only 32 studies on EACM carried out in Brazil, seven of which were published in national or international journals.

To update the above-mentioned review (Pedrini, 2010b), articles published in the Web of Science (WoS) and SciELO databases between 2010 and 2020 were searched using the term "Coastal Marine 
Environmental Education" in English (WoS) and Portuguese (SciELO). Twelve articles were retrieved, including seven in domestic and five in international journals. EACM has also been addressed in books (Pedrini, 2010a; Ghilardi-Lopes et al., 2012) and booklets (Kohler, 2012; Reis et al., 2018). A recent example is the book Coastal and Marine Environmental Education, which has eight chapters written by 20 researchers from six different teaching and research institutions in four Brazilian Federative Units (GhilardiLopes and Berchez, 2019). However, data in this field of research are limited and not added to national and international databases, limiting access by the scientific community.

PROMAR, EACM, and OL are initiatives to enhance public awareness on marine environments, ensuring their sustainable use. The latter two also seek to actively engage society in marine governance initiatives. Nevertheless, although PROMAR and EACM have been carried out for more than two decades in Brazil, the concept "maritime mentality" aroused no interest in academics and hence could not be established as a research subject, unlike EACM which is well consolidated but has limited impact (Pedrini, 2010b; Berchez et al., 2016). Therefore, further efforts are needed to achieve their goals in Brazil. Recently, Berchez et al. (2016) indicated that EACM activities should receive effective support from integrated networks, such as ReBentos (Coastal Benthic Habitats
Monitoring Network), which unites researchers from various regions of the country, and could facilitate creation of sub-networks and promote exchange of information, data, and results. Besides that, given its global nature of action and collaboration among countries and researchers, OL may help promote awareness of the ocean to meet the above objectives, especially when applied to wide-ranging proposals, such as actions developed in formal education.

\section{A STRATEGIC DECISION: FORMAL EDUCA- TION AND CURRICULA}

OL is a movement that, since its origin in the USA, has aimed to address marine issues in formal education. First, the essential content for school students was organized into seven essential principles (Figure 2) and 45 fundamental concepts of OL, so that their insertion into school curriculum could be facilitated. The challenges for educators and curriculum planners to incorporate $\mathrm{OL}$ into school curricula were primarily addressed by OL guidelines, using the National Science Education Standards of the United States as a reference, the so-called "Ocean Literacy Scope and Sequence for Grades K-12" (Strang et al., 2010).

However, such initial concern with school curriculum was gradually replaced by OL-research output, which began to branch out and incorporate activities, experiments, games, and online simulations (Foley et al., 2013; Fauville, 2017; Andrews et al., 2018)

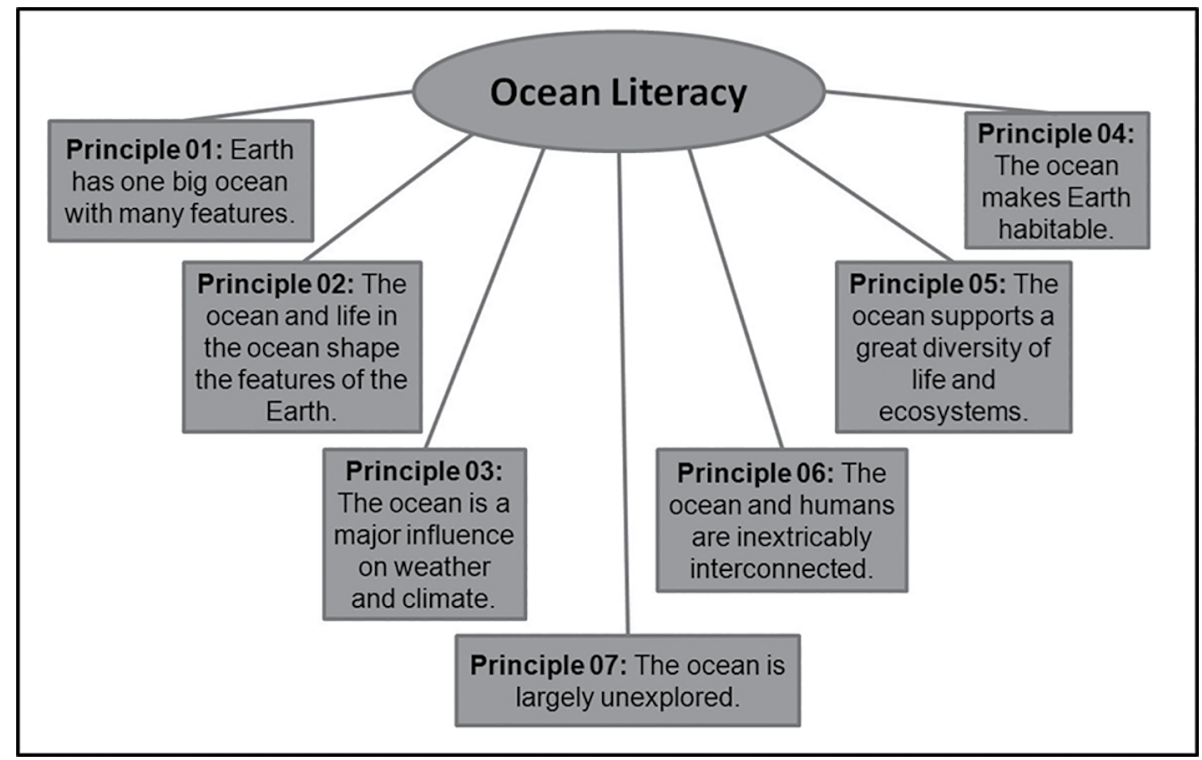

Figure 2. Ocean literacy principles (Ocean Literacy Network, 2020). 
as part of formal, but also, to a large extent, informal education (Marrero et al., 2019; Barrocosa et al., 2019). As OL studies and principles gained interest in non-formal education spaces, their concepts started to be disseminated through art movements, citizen science, and social media (Fauville et al., 2015; Kelly et al., 2019; Michałowska, 2020). Although knowledge about marine conservation has been expanded to different audiences, the approaches were insufficient to reach a wide audience because non-formal education does not ensure universal access (Barracosa et al., 2019; Kopke et al., 2019).

$\mathrm{OL}$ initiatives in non-formal education have the following limitations, they: (1) are usually short-lived (Pedrini, 2010b; Barracosa et al., 2019), (2) involve fewer people (Barracosa et al., 2019), and (3) their audience is already acquainted with environmental issues via social media (Kopke et al., 2019). In this regard, while informal education initiatives are needed to increase $\mathrm{OL}$ reach and effectiveness, a systematic investment to incorporate the seven OL principles and 45 concepts into formal education curricula would be crucial in the medium and long term.

Broadly, knowledge and information are provided by formal education, helping individuals to critically assess problems and challenges, as well as to make decisions for the collective good (Libâneo, 1994). Formal education is promoted in institutions (schools) and is a system of teaching and learning about content, with practices standardized and organized in a curricular manner (Gohn, 2006). School curriculum covers the contents to be taught in schools and guides how they should be provided over school years (Sacristán, 2013). In short, it provides schools with guidelines to set pedagogical goals and implement them within a school routine. In this sense, curriculum becomes a key strategy for $\mathrm{OL}$ to reach schools (Gough, 2017; McPherson et al., 2018). The importance of providing children with knowledge on marine environments has already been reported in some studies (Smith, 2002; Hartley et al., 2015; Visbeck, 2018).

Investment in formal education (such as training of educators, production of teaching material, curriculum and financial improvements, among others) is crucial for researchers, educators, and managers interested in using $\mathrm{OL}$ as a tool for engaging citizens in actions towards ocean conservation during the
Ocean Decade and beyond. In this sense, the first initiative to improve curricular competences and overcome challenges for $\mathrm{OL}$ inclusion in school schedule are curricular analysis and diagnosis. The following section presents a case study that investigates how ocean-related themes are present in Brazilian school supplies at both federal and regional levels.

OL relevance to school curriculum was stressed in the Sustainable Development Goals and Ocean Sustainability (United Nations, 2016). School is a common place where future decision makers are exposed to knowledge and skills needed in future actions. These are essential for students to act in this respect and achieve sustainable development goals. In the USA, the "Alignment of Ocean Literacy to the Next Generation Science Standards" was developed to set goals for learning at the elementary through high school levels (Ocean Literacy Network, 2020). Following the same path, Portugal produced the document "Conhecer o Oceano", which has OL principles and concepts to be worked on in subjects during child and adolescent school life (Costa and Caldeira, 2018). Although not yet widespread, these initiatives have been increasing in different countries (Hoffman \& Barstow, 2007; Castle et al., 2010; Gough, 2017; McPherson et al., 2018), and their main objectives are not just scientific subjects, but the entire curricular grid, in an interdisciplinary way (Santoro et al., 2017).

\section{A CASE STUDY: DIAGNOSIS OF BRAZILIAN SCHOOL CURRICULA}

Two federal documents provide guidelines for school curriculum content in Brazil: National Curriculum Parameters (Parâmetros Curriculares Nacionais [PCNs]) (Brasil, 1998) and Common National Curriculum Base (Base Nacional Curricular Comum [BNCC]) (Brasil, 2017). In addition to federal documents, each Federative Unit has its own curricular guidelines [Referenciais Curriculares Estaduais-RCs] based on either PCNs or BNCC. Federal guidelines ensure the teaching of common contents to all students, whereas RCs present contents and issues that are related to the cultural, social, and economic characteristics of each Federative Unit (Brasil, 2017). BNCC and BNCC-based RCs are the most recent documents and have been gradually implemented in schools since 2018, replacing PCNs and PCN-based RCs. A total of 55 documents (28 related to BNCC and BNCC-based 
$\mathrm{RCs}$, and 27 related to PCN and PCN-based RCs) were obtained between June 2019 and February 2020 from the Brazilian Ministry of Education website (http:// historiadabncc.mec.gov.br/\#/site/propostas and http://basenacionalcomum.mec.gov.br/implementacao). However, the PCN-based RC from the Federative Unit of Rio Grande do Norte was not available. These documents are related to elementary school (years 6 to 14) and present orientations on basic subjects and contents to be developed in schools.

A qualitative methodology was employed following the content analysis by Bardin (2011). First, the entire corpus of documents was read to get acquainted with the words therein $\left(6.4 \times 10^{6}\right.$ words); then, relevant words and themes were defined according to their direct connection with the goals of the study or the content to which they refer. Secondly, ocean and marine environment-related words and themes were registered according to diversity (different words registered) and citation (numbers of times they were cited). Only words explicitly related to the ocean and marine environments were retained, ruling out those transversely related to the subject, such as $\mathrm{O}_{2}$ sources and $\mathrm{CO}_{2}$ sinks, so that ambiguous results could be avoided. Reading and recording were performed twice by one of the researchers, and a third time using the word search tool provided by Adobe Reader/ Acrobat to confirm the records. Results from the three word searches in documents were consistent (with an average of $1 \%$ difference between the three different readings).

The quantitative methodology included descriptive statistics (average and standard deviation) and exploratory multivariate statistics, which has proven successful in different areas of research and allows evaluation of many variables simultaneously (Hair et al., 2009; Abdi and Williams, 2010). Principal Component Analysis (PCA) was carried out using a total of 21 variables, 19 variables corresponding to the number of citations of each of the 19 registered words, a variable related to the number of registered words and a variable related to the total number of citations. These variables were grouped by PCN-based and BNCC-based RCs of each of the five Brazilian regions (total of ten groups).

Hierarchical analysis was used to verify statistical differences considering (1) each one of the 27
Federative Units, (2) each one of the five geographic regions, and (3) PCA analysis differences. A pairwise analysis of variance was conducted to compare two datasets (Federative Units, Brazilian geographic regions, and two PCA-identified groups) by the MannWhitney U-test, whereas the Kruskal-Wallis test was used to compare more than two datasets (all Federative Units and Brazilian geographic regions). Non-parametric statistics were used once ShapiroWilk and Levene tests had shown non-normal distribution and heteroscedasticity of variance $(p>0.05)$ for the data. A Bonferroni correction was performed to avoid errors from multiple comparisons. All analyses were performed using PAST software version 2.08 (Hammer et al., 2001).

A total of 19 words and 797 citations related to marine environments were identified; it is possible to observe a greater variation of words as well as a greater number of citations in the BNCC-based RCs (Table 2). PCN-based RCs and BNCC-based RCs were statistically different for citations (Kruskal-Wallis test, $p=0.0009$ ). The Federative Units responsible for such difference were determined using the Mann-Whitney U-test and were statistically significant in 12 of the 1,431 tests, after Bonferroni's correction. Table 3 shows comparisons between Federative Units with statistically significant results. Two relevant trends can be inferred by combining results in Tables 2 and 3:

1) PCN-based RCs, which have been gradually replaced since 2018, addressed marine-related issues less frequently than did BNCC-based RCs, demonstrating a recent trend to include marine environment contents into Brazilian school curriculum.

2) A lack of relationship between presence of marine and coastal themes with Coastal Federative Units. Therefore, the statement by Hoffman \& Barstow (2007), in which proximity of the ocean facilitates incorporation of marine environment-related disciplines in an educational setting, cannot be confirmed in this case study.

Despite the trends, the range of marine issues addressed in schools may be much smaller than the above-mentioned, given free interpretations and operational differences between schools and teachers when implementing such topics. Therefore, 19 words and 797 citations can have a much smaller impact than it appears at first glance. 
Table 2. Registered words and their citation scores in the curricular guidelines of Federative Units in Brazil (PCN-based and BNCC-based). Average, standard deviation, and result of the Kruskal-Wallis test are also shown.

\begin{tabular}{|c|c|c|c|c|c|c|c|}
\hline Words & $\begin{array}{c}\text { PCN- } \\
\text { based RC }\end{array}$ & Average & $\begin{array}{l}\text { Standard } \\
\text { Deviation }\end{array}$ & $\begin{array}{l}\text { BNCC- } \\
\text {-based RC }\end{array}$ & Average & $\begin{array}{l}\text { Standard } \\
\text { Deviation }\end{array}$ & $\begin{array}{c}\text { Kruskal- } \\
\text {-Wallis } \\
\text { test }\end{array}$ \\
\hline Aquática (Aquatic) & 47 & 1.74 & 2.31 & 70 & 2.59 & 2.78 & \\
\hline $\begin{array}{l}\text { Aquicultura } \\
\text { (Aquaculture) }\end{array}$ & 1 & 0.04 & 0.19 & - & - & - & \\
\hline Costeiro (Coastal) & - & - & - & 13 & 0.48 & 0.85 & \\
\hline $\begin{array}{l}\text { Litoral/Litorâneo } \\
\text { (Littoral) }\end{array}$ & 8 & 0.30 & 0.67 & 22 & 0.81 & 0.92 & \\
\hline Mangue (Mangrove) & 2 & 0.07 & 0.27 & 9 & 0.33 & 0.68 & \\
\hline Mar (Sea) & 39 & 1.44 & 2.10 & 76 & 2.81 & 2.20 & \\
\hline Maremoto (Seaquake) & 6 & 0.22 & 0.80 & 1 & 0.04 & 0.19 & \\
\hline Marinha (Marine) & 2 & 0.07 & 0.27 & 7 & 0.26 & 0.45 & \\
\hline Marinheiro (Sailor) & - & - & - & 1 & 0.04 & 0.19 & \\
\hline Marítima (Maritime) & 35 & 1.30 & 1.73 & 118 & 4.37 & 2.50 & $p=0.169$ \\
\hline $\begin{array}{l}\text { Maritimidade } \\
\text { (Maritimity) }\end{array}$ & 1 & 0.04 & 0.19 & 3 & 0.11 & 0.32 & \\
\hline Oceânica (Oceanic) & 1 & 0.04 & 0.19 & 37 & 1.37 & 0.69 & \\
\hline Oceano (Ocean) & 32 & 1.19 & 1.44 & 86 & 3.19 & 1.33 & \\
\hline Praia (Beach) & 16 & 0.59 & 1.12 & 21 & 0.78 & 1.34 & \\
\hline Restinga (Restinga) & - & - & - & 4 & 0.15 & 0.60 & \\
\hline $\begin{array}{l}\text { Submarino } \\
\text { (Underwater) }\end{array}$ & 3 & 0.11 & 0.32 & - & - & - & \\
\hline $\begin{array}{l}\text { Transmarina } \\
\text { (Transmarina) }\end{array}$ & - & - & - & 1 & 0.04 & 0.19 & \\
\hline Tsunami (Tsunami) & 9 & 0.33 & 0.96 & 74 & 2.74 & 1.10 & \\
\hline Ultramarina (Overseas) & 2 & 0.07 & 0.27 & 6 & 0.22 & 0.64 & \\
\hline $\begin{array}{l}\text { Total number of } \\
\text { words }\end{array}$ & 15 & & & 17 & & & \\
\hline $\begin{array}{l}\text { Total number of } \\
\text { citations }\end{array}$ & 204 & 7.56 & 6.36 & 549 & 20.33 & 10.46 & \\
\hline
\end{tabular}

Table 3. Significant results of the U-Mann-Whitney test ( $p$ values) for comparisons between PCN- and BNCC-based RCs of each Federative Unit in Brazil.

\begin{tabular}{lcccc}
\hline & Ceará & Rio Grande do Norte & Mato Grosso & Paraná \\
\hline Tocantins & 0.018 & 0.018 & 0.018 & 0.018 \\
Acre & 0.007 & 0.007 & 0.007 & 0.007 \\
Mato Grosso do Sul & 0.018 & 0.018 & 0.018 & 0.018 \\
\hline
\end{tabular}

When compared to other countries, Brazil presented a greater number of marine environment topics. Castle et al. (2010), for example, analyzed the English school curriculum and observed that the word "ocean" was not mentioned, and the words "marine" and "coastal" were mentioned only three times. Similarly, the words "ocean" and "marine" were not mentioned in the Australian school curriculum (Gough, 2017). Although there is no defined number of words to infer a citizen as ocean literate, the marine topics and themes present in the Brazilian curriculum account for just a small portion of the analyzed documents (a frequency of 0.0001 in the total number of words referring to contents). Furthermore, 
the inclusion of these in classrooms depends on the mediation of the teacher. Thus, it is important both to expand the presence of these themes in Brazilian curricula, as well as to provide training to teachers so that they approach these themes in accordance with the 7 principles and 45 concepts of OL.

The Sciences, History, and Geography disciplines had the most words and citations related to the ocean and marine environment $(88.7 \%$ of the total registered). Even though these can cover a wide range of coastal and marine topics during all years of schooling, OL still needs to target other primary school subjects. Since marine topics are interdisciplinary in nature, OL can be included in almost all school subjects. However, as already mentioned, these initiatives are dependent on the interests of teachers and schools.

In PCA, principal components 1 and 2 explained $98.68 \%$ of the total variation and recovered $97.90 \%$ and $0.78 \%$ of the total variation, respectively. Therefore, only PC1 was required to explain the majority of the variation in the data. PC1 was highly correlated (correlation index $=0.93$ ) with total frequency of citations. Scatter plots distinguished two groups separated by PC1: one formed by all PCN-based and BNCC-based RCs in southern and southeastern regions, and another, with a higher number of OL related terms, formed by BNCC-based RCs in northern, northeastern, and midwestern Brazilian regions (Figure 3). No midwestern states are located on the Brazilian Coast. Therefore, this is a counter-intuitive result, although relevant, since marine-related topics should not be restricted to coastal regions (Dupont and Fauville, 2017; Santoro et al., 2017). In contrast, some Federative Units in the northern and all in the northeastern regions are located on the coast, with coastal tourism being one of their main economic activities (Diegues, 1999; Jablonski and Filet, 2008). Meanwhile, the impact of such economic activity (Jablonski and Filet, 2008; Silva et al., 2014; Martins et al., 2017) may explain increases in marine topics in the school curriculum in those regions.

Differing from the north and northeast regions, the curriculum documents from the south and southeast regions were the ones that presented a smaller number of terms related to the ocean and the marine environment, although these regions receive large investments from the oil and gas industry. Offshore oil production in the Bacia de Campos since the early 2000 s has caused intense and disordered urban sprawl in coastal cities near oil-exploration areas,

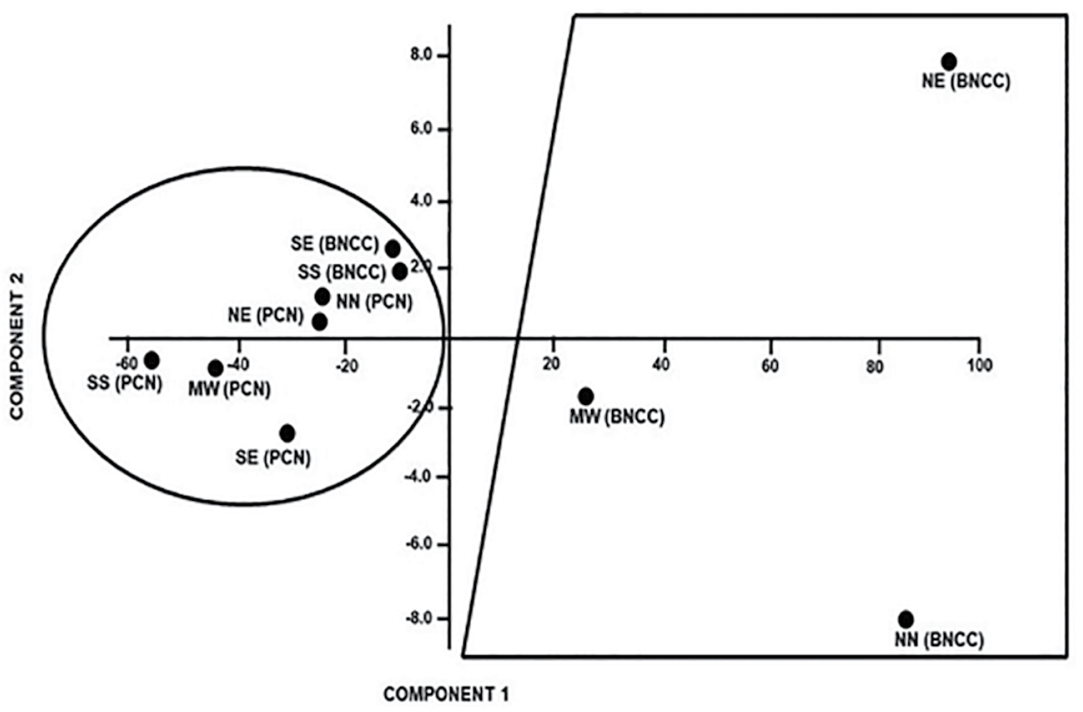

Figure 3. Scatter plot of the principal component analysis (PCA). RCs were divided according to Brazilian geographic regions and origin (based on either PCN or BNCC). Group 1 (marked by the ellipse) is formed by all PCN-based and BNCC-based RCs located in southern and southeastern regions, and Group 2 (marked by the trapezium) formed by BNCC-based RCs located in northern, northeastern, and midwestern regions. The acronyms stand for the following: MW- Midwestern region; NE- Northeastern region; NN- Northern region; SE- Southeastern region, and SS- Southern region. 
especially in Espírito Santo and Rio de Janeiro States (Jablonski and Filet, 2008; Neto et al., 2018). Oil royalties have raised investments in education in these Federative Units, but did not focus on the inclusion of marine environment topics in the school curriculum. On the other hand, several informal environmental education activities have been developed therein, providing basic information on the topic (Berchez et al., 2016; Pedrini et al., 2019). Pedrini et al. (2019) showed that such initiatives are not always sustainable in the long term and reach a limited audience. Therefore, participative management should be implemented to rethink the school curricula and promote long-term changes in public knowledge.

The curriculum diagnosis, combined with proposals in specialized literature (Castle et al., 2010; Gough, 2017; McPherson et al., 2018), indicate that investments should be made towards actions to introduce OL principles and concepts in formal Brazilian education. This can increase knowledge and empathy for challenges posed by the Ocean Decade, favoring a bottom-up management model, where different actors can be active and influential in establishing public policies.

\section{STRATEGIES TO BE IMPLEMENTED DURING THE OCEAN DECADE IN BRAZIL AND GLOB- AL SOUTH}

The Decade of Ocean Science for Sustainable Development was proposed by the United Nations in 2017; it began recently in January 2021 and will continue until 2030. Its main goals are to engage all stakeholders in marine management issues for the benefit of humanity, promoting scientific research to ensure ocean productivity, resilience, and sustainability (United Nations, 2018). To achieve such goals, OL seems to be an initiative that has been gaining prominence, as it integrates and engages different audiences in participatory governance and decisionmaking on marine ecosystem conservation. In this sense, through school curriculum proposals, formal education has the potential to widely spread the knowledge required to engage individuals in the Ocean Decade actions. Based on the results for the case study in Brazilian curricula, we drew up proposals for actions to improve OL at all formal education levels, serving as an effective tool for participatory governance implementation in the Ocean Decade.
The following strategies are proposed to be implemented in Brazil during the Ocean Decade, but can be expanded to cover the Global South:

\section{Engage the Curricula}

- To review documents that could guide school curriculum development in several Global South countries in terms of the presence of marine environment-related topics and themes and/ or OL principles and concepts. The review should be based on quali-quantitative surveys as those in the case study presented.

- To develop guidelines to include $\mathrm{OL}$ into the formal school curriculum context in all Global South countries.

- To produce supporting materials on $\mathrm{OL}$, such as booklets, educational books, and pedagogical resources, as well as materials to address problems identified during curricular analysis.

Stakeholders may easily reach a consensus on the integration of ocean-related contents into school curricula, but its implementation depends on efforts from educational and research institutions. This first set of actions meets the need for basic research on the impact of marine environment-related contents in school curriculum guidelines. Since each country has its own specificities, actions should be carried out in each country of the Global South. Analytical methodologies comparing countries are essential and allow identification of patterns and implementation of joint actions. The quali-quantitative methods used in the case study could effectively identify patterns, limitations, and trends in the Brazilian school curriculum. Therefore, they can help coordinate actions and serve as a reference to other countries, as reported by Strang et al. (2010), who produced guidelines for $\mathrm{OL}$ using the National Science Education Standards of the United States as a reference. A diagnosis would enable identifying the main gaps in $\mathrm{OL}$ and guide production of teaching materials to fill them up. Guidelines and teaching materials can be produced in the medium term by collaborative work among teachers, researchers, and educational managers. 


\section{Diffusion of Ocean Literacy}

- To create an online platform to disseminate and share materials, practices, and activities developed in schools, promoting OL.

- To encourage partnerships among schools within the same region and country and among countries to coordinate actions.

- To promote formation of school science clubs focused on OL.

- To encourage continuity of the National Oceanography Olympics and inclusion of ocean-related themes into the well-established Olympics such as the Brazilian Olympics in Biology, Astronomy, and Mathematics, thus encouraging interdisciplinarity on the oceanic theme.

- To hold regional and federal events that promote $\mathrm{OL}$ and include the theme in traditional events such as the National Week of Science and Technology (SNCT) and the Brazilian Science and Engineering Fair (FEBRACE).

OL-promoting strategies in formal education should encourage coordination and sharing of information, actions, and practices in schools at regional and federal levels, both in Brazil and other countries in the Global South. These actions can be performed via digital platforms built in the medium term by Brazilian governmental agencies (Ministry of Education and Ministry of Science and Technology) and international organizations (UNESCO and International Oceanographic Commission). To this end, UNESCO has launched the platform Ocean Literacy for All (https://oceanliteracy. unesco.org/?post-types=all\&sort=popular) to share resources; however, most of the materials available are in English, which limits fundamental education teachers who do not speak English. In this sense, local or multi-country platforms in the same or similar languages would facilitate access and use as in the Brazilian initiatives "UNESCO Chair for Ocean Sustainability" (http://catedraoceano.iea.usp.br/) and "Maré de Ciência" (https://maredeciencia.com.br/). Such platforms develop projects for dissemination, coordination, and sharing of $\mathrm{OL}$ initiatives.

Apart from digital platforms, one can include knowledge sharing among students and optimal environments for OL teaching in schools, such as science clubs to develop ocean education. At regional and federal levels, OL teaching initiatives can take place through state and national fairs addressing oceanic issues as themes. Much is said about the interdisciplinary nature of ocean sciences (Santoro et al., 2017), which would then facilitate including ocean themes in School Olympics, such as the well-established Brazilian Biology Olympics (OBB), Astronomy Olympics (OBA), and Mathematics Olympics (OBMEP).

\section{Formal Teacher Training in Ocean Literacy}

- To promote continuous training to elementary and middle schooling teachers on $\mathrm{OL}$.

- To develop outreach and specialization courses on OL for teachers.

- To develop subject(s) in undergraduate pedagogy courses and pre-service teachers including $\mathrm{OL}$ in the syllabus.

$\mathrm{OL}$ discussions should take place in universities during teacher training, either in undergraduate or extracurricular courses. Training and continuing education may be offered to school teachers. Such actions can be undertaken in the short and medium terms by government education agencies, both at local and regional levels, in training bodies in partnership with public universities. Teachers can also be trained by extension and specialization courses. In Brazil, for example, there is a specialization course in Marine Sciences Applied to Education, which is offered by the Federal Institute of Santa Catarina, Campus Itajaí.

\section{Research Network on Ocean Literacy}

- To assess the level of knowledge of people about marine environments and their attitudes, values, and behaviors towards these ecosystems in all countries of the Global South.

- To encourage research on OL via calls for thematic research projects and special issues in periodicals.

- To embolden the formation of undergraduate and graduate students in the area.

- To support continuity of the Latin American Ocean Education Network (RELATO) and creation of networks involving stakeholders from all regions of the Global South. 
- To establish OL data sharing policies among the Global South countries to speed up policy-making therein.

Since it is still incipient in Brazil and other countries in the Global South, academic research on OL should be developed, and the results published in international journals. Allied to that, standardized tools may be developed and adopted to compare the results from different regions. To this end, the questionnaire proposed by The International Ocean Literacy Survey, which has been translated into 17 languages (Fauville et al., 2019), can be used. With all these results, a database of developing countries should be created.

Finally, social participation, promotion of knowledge, and citizen empowerment should be encouraged, so that people could act as active agents in problem solving. Although informal learning acts on several fronts, formal education at schools covers most of the population. Therefore, this learning path is crucial to increase public knowledge and encourage bottom-up governance practices (Kuiper, 2003; Castle et al., 2010; Visbeck, 2018).

In short, all above-mentioned strategies can improve OL knowledge in formal education and enhance awareness of marine ecosystems among students, teachers, and other stakeholders. These measures can be developed in the short, medium, and long term and put into practice in Global South countries.

\section{CONCLUSIONS}

The quali-quantitative analysis carried out in this manuscript showed that the scientific production in the field of ocean literacy is still low, but has been increasing over the last ten years. Content analysis of internationally published articles revealed five recurring themes (Knowledge/Perception; Ocean Literacy Challenges, Opportunities, Recommendations; Teaching; Communication; Citizen science). In Brazil, the production is concentrated in the field of Marine Coastal Environmental Education, but restricted to national journals, books, and booklets, thus with a limited range of information produced in this field.

Regarding the case study on Brazilian school curricula, it was found that there are a larger number of topics on marine environments than other countries have; however, this theme still represents a very small fraction of Brazilian curricula. Thus, it is necessary to expand the contents related to ocean and marine environments to provide students with basic knowledge about the importance and functions of these environments, as well as their conservation. School curricula are heterogeneous among Federative Units in Brazil, with a recent trend to include marine contents as could be noticed in BNCC based-RCs.

In short, during the Ocean Decade, Brazil and other Global South countries should invest in introducing Ocean Literacy principles and concepts in formal education. This can raise awareness of marine environments among students, teachers, and other stakeholders.

\section{ACKNOWLEDGMENTS}

The authors would like to acknowledge the very valuable contributions of the anonymous reviewers and thanks CAPES (Coordenação de Aperfeiçoamento de Pessoal de Nível Superior) for the scholarship granted to MRD (post-doc).

\section{AUTHOR CONTRIBUTIONS}

C.E.P.: Investigation; Methodology; Writing - original draft; E.P.S.: Conceptualization; Supervision; Writing - original draft; L.A.B.A.: Writing - review \& editing;

J.M.F.: Writing - review \& editing;

C.F.S.A.: Writing - review \& editing;

M.R.D.: Formal analysis; Methodology; Writing - original draft.

\section{REFERENCES}

ABDI, H. \& WILLIAMS, L. J. 2010. Principal components analysis. Wiley Interdisciplinary Reviews: Computational Statistics, 2(4), 433-459.

ANDREWS, S., STOCKER, L. \& OECHEL, W. 2018. Underwater photo-elicitation: a new experiential marine education technique. Australian Journal of Environmental Education, 34(1), 33-60.

BARDIN, L. 2011. Análise de conteúdo. São Paulo: Edições 70.

BARRACOSA, H., DE LOS SANTOS, C. B., MARTINS, M., FREITAS, C. \& SANTOS, R. 2019. Ocean literacy to mainstream ecosystem services concept in formal and informal education: the example of coastal ecosystems of southern Portugal. Frontiers in Marine Science, 6, 626.

BERCHEZ, F. A. S., GHILARDI-LOPES, N. P., CORREIA, M. D., SOVIERZOSKI, H., PEDRINI, A. G., URSI, S., KREMER, L. P., ALMEIDA, R., SCHAEFFER-NOVELLI, Y., MARQUES, V. \& BROTTO, D. S. 2016. Marine and coastal environmental education in the context of global climate changes - synthesis and subsidies for ReBentos (Coastal Benthic Habitats Monitoring Network). Brazilian Journal of Oceanography, 64(spe2), 137-156. 
BERCHEZ, F. A. S., GHILARDI, N. P., ROBIM, M. J., PEDRINI, A. G., HADEL, V. F., FLUCKIGER, G., SIMÕES, M., MAZZARO, R., KLAUSENER, C., SANCHES, C. \& BESPALEC, P. 2007. Projeto trilha subaquática: sugestão de diretrizes para a criação de modelos de educação ambiental em unidade de conservação ligadas a ecossistemas marinhos. OLAM Ciência \& Tecnologia, 7(3), 181-209.

BRASIL. Ministério da Educação. 1998. Parâmetros Curriculares Nacionais. Brasília: Ministério da Educação.

BRASIL. Ministério da Educação. 2017. Base Nacional Comum Curricular: educação é a base. Brasília: Ministério da Educação.

CASTLE, Z., FLETCHER, S. \& MCKINLEY, E. 2010. Coastal and marine education in schools: constraints and opportunities created by the curriculum, schools and teachers in England. Ocean Yearbook Online, 24(1), 425-444.

CEMBRA (Centro de Excelência para o Mar Brasileiro). 2012. O Brasil e o mar no século XXI: relatório aos tomadores de decisão do país. Niterói: CEMBRA/BHMN (Base de Hidrografia da Marinha em Niterói).

COSTA, S. \& CALDEIRA, R. 2018. Bibliometric analysis of ocean literacy: an underrated term in the scientific literature. $\mathrm{Ma}$ rine Policy, 87, 149-157.

DIEGUES, A. C. 1999. Human populations and coastal wetlands: conservation and management in Brazil. Ocean \& Coastal Management, 42(2-4), 187-210.

DUPONT, S. \& FAUVILLE, G. 2017. Ocean literacy as a key toward sustainable development and ocean governance. In: NUNES, P., SVENSSON, L. E. \& MARKANDYA, A. (eds.). Handbook on the economics and management of sustainable oceans. Cheltenham: Edward Elgar Publishers.

FAUVILLE, G. 2017. Questions as indicators of ocean literacy: students' online asynchronous discussion with a marine scientist. International Journal of Science Education, 39(16), 2151-2170.

FAUVILLE, G., DUPONT, S., VON THUN, S. \& LUNDIN, J. 2015. Can facebook be used to increase scientific literacy? A case study of the Monterey Bay Aquarium Research Institute Facebook page and ocean literacy. Computers \& Education, 82(1), 60-73.

FAUVILLE, G., STRANG, C., CANNADY, M. A. \& CHEN, Y. F. 2019. Development of the international ocean literacy survey: measuring knowledge across the world. Environmental Education Research, 25(2), 238-263.

FOLEY, J. M., BRUNO, B. C., TOLMAN, R. T., KAGAMI, R. S., HSIA, M. H., MAYER, B. \& INAZU, J. K. 2013. C-MORE science kits as a classroom learning tool. Journal of Geoscience Education, 61(3), 256-267.

FRENCH, V., CHU, N. C., SANTORO, F., SOUSA PINTO, I., BORGES, D. \& MCDONOUGH, N. 2015. Review of ocean literacy in European maritime policy. Belgium: EU Sea Change Project.

GHILARDI-LOPES, N. P. \& BERCHEZ, F. A. S. 2019. Coastal and marine environmental education. Switzerland: Springer Nature.

GHILARDI-LOPES, N. P., HADEL, V. F. \& BERCHEZ, F. 2012. Guia para educação ambiental em costões rochosos. Porto Alegre: Artmed.
GHILARDI-LOPES, N. P., KREMER, L. P. \& BARRADAS, J. I. 2019 The importance of "Ocean Literacy" in the Anthropocene and how environmental education can help in its promotion. In: GHILARDI-LOPES, N. P. \& BERCHEZ, F. A. S. (eds.). Coastal and marine environmental education. Switzerland: Springer Nature.

GOHN, M. G. 2006. Educação não-formal, participação da sociedade civil e estruturas colegiadas nas escolas. Ensaio: Avaliação e Políticas Públicas em Educação, 14(50), 27-38.

GOUGH, A. 2017. Educating for the marine environment: challenges for schools and scientists. Marine Pollution Bulletin 124(2), 633-638.

HAIR, J. F. J., BLACK, W. C., BABIN, B. J., ANDERSON, R. E. \& TATHAN, R. L. 2009. Análise multivariada de dados. Porto Alegre: Bookman.

HAMMER, O., HARPER, D. A. T. \& RYAN, P. D. 2001. PAST: paleontological statistics software package for education and data analysis. Palaeontologia Electronica, 4(1), 1-9.

HARTLEY, B. L., THOMPSON, R. C. \& PAHL, S. 2015. Marine litter education boosts children's understanding and self-reported actions. Marine Pollution Bulletin, 90(1-2), 209-217.

HOFFMAN, M. \& BARSTOW, D. 2007. Revolutinizing earth system science education for the 21st century, report and recommendations from a 50-state analysis of earth science education standards. Cambridge: NOOA (National Oceanic and Atmospheric Administration)

IOC (Intergovernmental Oceanographic Commission), UNESCO (United Nations Educational, Scientific and Cultural Organization). 2018. Revised roadmap for the UN decade of ocean science for sustainable development. Paris: UNESCO Publishing.

JABLONSKI, S. \& FILET, M. 2008. Coastal management in Brazil - a political riddle. Ocean \& Coastal Management, 51(7), 536-543.

KELLY, R., FLEMING, A., PECL, G. T., RICHTER, A. \& BONN, A. 2019. Social license through citizen science: a tool for marine conservation. Ecology and Society, 24(1), 16.

KOHLER, M. C. 2012. Cartilha de educação Ambiental marinha: livro do professor e do aluno. Santos: Editora Comunnicar.

KOPKE, K., BLACK, J. \& DOZIER, A. E. 2019. Stepping out of the ivory tower for ocean literacy. Frontiers in Marine Science, 6, 60.

KUIJPER, M. W. M. 2003. Marine and coastal environmental awareness building within the context of UNESCO's activities in Asia and the Pacific. Marine Pollution Bulletin, 47(1-6), 265-272.

LIBÂNEO, J. C. 1994. Didática. São Paulo: Cortez Editora.

MARRERO, M. E., PAYNE, D. L. \& BREIDAHL, H. 2019. The case for collaboration to foster global ocean literacy. Frontiers in Marine Science, 6, 325.

MARTINS, K. A., PEREIRA, P. S., SILVA-CASARÍN, R. \& NETO, A. V. N. 2017. The influence of climate change on coastal erosion vulnerability in Northeast Brazil. Coastal Engineering, 59(2), 1740007-1-1740007-25.

MCPHERSON, K., WRIGHT, T. \& TYEDMERS, P. 2018. Examining the Nova Scotia science curriculum for international ocean literacy principle inclusion. International Journal of Learning, Teaching and Educational Research, 17(11), 1-16. 
MICHAŁOWSKA, M. 2020. Artists in the face of threats of climate change. Oceanologia, 62(4), 565-575.

MOKOS, M., CHEIMONOPOULOU, M., KOULOURI, P., PREVIATI, M., REALDON, G., SANTORO, F., MOGIAS, A., BOUBONARI, T., GAZO, M., SATTA, A., IOAKEIMIDIS, C., TOJEIRO, A., CHICOTE, C., PAPATHANASSIOU, M. \& KEVREKIDIS, T. 2020. Mediterranean sea literacy: when ocean literacy becomes region-specific. Mediterranean Marine Science, 21, 592-598.

SILVA NETO, R., OLIVEIRA, F. G., QUINTO JÚNIOR, L. P. \& GOMES FILHO, H. 2018. Impactos socioeconômicos das atividades do petróleo e de suas rendas nos municípios do circuito espacial do petróleo do estado do Rio de Janeiro. Revista Brasileira de Gestão e Desenvolvimento Regional, 14(3), 293-316.

NOOA (National Oceanic and Atmospheric Administration). Ocean Literacy Network. 2013. Ocean literacy: the essential principles and fundamental concepts of ocean sciences for learners of all ages version 2 [online]. Washington: NOAA (National Oceanic and Atmospheric Administration). Available at: https://www.coexploration.org/oceanliteracy/documents/OceanLitChart.pdf [Acessed: 26 Nov 2020].

NOOA (National Oceanic and Atmospheric Administration). Ocean Literacy Network. 2020. Ocean literacy: the essential principles and fundamental concepts of ocean sciences for learners of all ages version 3 [online]. Washington: NOAA (National Oceanic and Atmospheric Administration). Available at: https://oceanliteracy.unesco.org/wp-content/uploads/2020/09/OceanLiteracyGuide_V3_2020-8x11-1.pdf [Acessed: 03 May 2021].

PEDRINI, A. G. 2010a. Educação ambiental marinha e costeira no Brasil. Rio de Janeiro: Editora da Universidade do Estado do Rio de Janeiro.

PEDRINI, A. G. 2010b. Educação Ambiental Marinha e Costeira no Brasil; aportes para uma síntese. In: PEDRINI, A. G. (org.). Educação ambiental marinha e costeira no Brasil. Rio de Janeiro: Editora da Universidade do Estado do Rio de Janeiro.

PEDRINI, A. G., BROTTO, D. S., LOPES, M. C., FERREIRA, L. P. \& GHILARDI-LOPES, N. 2013. Percepções sobre meio ambiente e o mar por interessados em ecoturismo marinho na área de proteção ambiental marinha de Armação de Búzios, Estado do Rio de Janeiro, RJ, Brasil. Pesquisa em Educação Ambiental, 8(2), 59-75.

PEDRINI, A. G., KREMER, L. P., BROTTO, D. S. \& SILVA, V. R. F. 2019. Emblematic coastal and marine environmental education projects in Brazil. In: GHILARDI-LOPES, N. P. \& BERCHEZ, F. A. S. (eds.). Coastal and marine environmental education. Switzerland: Springer Nature.

PEW OCEANS COMMISSION. 2003. America's living oceans: charting a course for sea change. a report to the nation [online]. Arlington: PEW Oceans Commission. Available at: https:// www.pewtrusts.org/-/media/assets/2003/06/02/full_report.pdf [Acessed: 01 Dec 2020].
REIS, R. A., PONTES, J. S., RAMOS, M. C., MALAQUIAS, J. S. \& FELÍCIO, F. B. 2018. O mar e nós - mergulhando na biodiversidade do litoral paranaense. Ponta do Paraná: Associação MarBrasil.

SACRISTÁN, J. G. 2013. O que significa currículo. In: SACRISTÁN, J. G. (org.). Saberes e incertezas sobre o currículo. Porto Alegre: Penso.

SANTORO, F., SANTIN, S., SCOWCROFT, G., FAUVILLE, G. \& TUDDENHAM, P. 2017. Ocean literacy for all - a toolkit. Paris: Unesco Venice Office.

SCHOEDINGER, S., TRAN, L. U. \& WHITLEY, L. 2010. From the principles to the scope and sequence: a brief history of the ocean literacy campaign. Current: The Journal of Marine Education, 3, 3-7.

SILVA, R., MARTINEZ, M. L., HESP, P. A., OSORIO, A. F., MARTELL, R., FOSSATI, M., SILVA, G. M., MARTIÑO-TAIA, I., PEREIRA, P., CIENGUEGOS, R., KLEIN, A. \& GOVAERE, G. 2014. Present and future challenges of coastal erosion in Latin America. The Journal of Coastal Research, 71, 1-16.

SMITH, H. D. 2002. The role of the social sciences in capacity building in ocean and coastal management. Ocean \& Coastal Management, 45(9), 573-582.

STEFANELLI-SILVA G., PARDO, J. C. F., PAIXÃO, P. \& COSTA, T. M. 2019. University extension and informal education: useful tools for bottom-up ocean and coastal literacy of primary school children in Brazil. Frontiers in Marine Science, 6, 389.

STRANG, C., DIRANNA, K. \& TOPPS, J. 2010. Developing the ideas of ocean literacy using conceptual flow diagrams. Current: The Journal of Marine Education, 3, 2762.

TUDDENHAM, P., GRIGOROV, I., BISHOP, T., BREIDAHL, H., COPEJANS, E., CIRA, M., CROUCH, F., FAUVILLE, G., HEANEY, S., JOYCE, J., KEENER-CHAVIS, P., KRIMPHOFF, H., MODINOU, I., PARR, J., ROCHA, R., RYAN, M., SAVAGE, S., SEYS, J., SPICER, J., STEWART, A., SUAREZ, M., WARD, M. \& ZWARTJES, L. 2013. Vision Statement on Ocean Literacy and Atlantic Ocean Cooperation between European Union, United States of America \& Canada. In: Conference Transatlantic Ocean Literacy (TOL) Workshop, 5-6 Sept 2013, Plymouth, United Kingdom. Plymouth: TOL.

U. S. COMMISSION ON OCEAN POLICY. 2004. An ocean blueprint for the 21st Century. Final report [online]. Washington: U.S. Commission on Ocean Policy. Available at: https://govinfo.library.unt.edu/oceancommission/ documents/full_color_rpt/000_ocean_full_report.pdf [Acessed: 01 Dec 2020].

VISBECK, M. 2018. Ocean science research is key for a sustainable future. Nature Communications, 9, 690 . 